\title{
THE PRINCIPLES OF THE CORPORATE GOVERNANCE IN BANKS AND LEGISLATION OF REPUBLIC OF SERBIA
}

\begin{abstract}
Complex relations, a frequent separation of ownership, management, and control functions in banks, as well as turbulent and changeable market conditions make responsible, fair, and transparent corporate governance mechanisms extremely important for these financial institutions. "The culture" of the corporate governance is incorporated into the banking sector of Republic of Serbia and it is based on the national legislation and international governance standards. The aim of the research is to analyze the level of the implementation of international principles of corporate governance in the Serbian banking sector and to assess the adequacy and strength of the national legal and regulatory framework to enable and support such an act. The descriptive method, an analysis and synthesis technique, as well as the analysis of the content of laws, reports, and available national and foreign literature in the field of corporate governance, were used for the preparation of this paper. The result of the research implies the confirmed assumption that the legal and regulatory framework of corporate governance in the banking sector of Republic of Serbia makes the implementation of the international principles of corporate governance possible and sufficiently supports it.
\end{abstract}

Keywords: corporate governance, banking, Law on banks, Republic of Serbia.

\footnotetext{
* Ph.D. student, The Faculty of Economics in Subotica, The University of Novi Sad, e-mail: nevenajolovic@uns.ac.rs

** Assistant professor, The Faculty of Economics in Subotica, The University of Novi Sad - A full professor, The Faculty of Law for Commerce and Judiciary, The University of Business Academy in Novi Sad, e-mail: m.mijatovic@ef.uns.ac.rs
} 


\section{Introduction}

Becht and co-authors stated that financial crises, pension funds reform, privatization, and capital market integration represent a series of structural events that have intensified the processes of strengthening corporate governance in recent decades. ${ }^{1}$ The liberalization and deregulation of global financial markets led to efforts of creating international regulatory standards that could shape the governance activities of corporations and financial institutions. ${ }^{2}$ The process of creating an international corporate governance framework was led by the OECD, and the development of corporate governance standards has enriched previous regulations with six current and comprehensive principles. Thus, in 1999, the first steps were taken in assisting states to adequately assess and improve the regulatory framework for corporate governance within their borders.

Corporate governance in the banking sector of the Republic of Serbia has been a very attractive and dynamic research area over the past decades, but also a field of dynamic changes of legislation, corporative procedures, and norms. ${ }^{3}$ Weak institutional frameworks, poor governance practices, and a lack of awareness of the importance of good corporate governance in banking have often been a significant obstacle to the development of the national financial market in the past. For that reason, it is clear why further reforms of the legal and regulatory framework and the quality of the implementation and monitoring process of corporate governance will significantly shape the banking reality, i.e. determine the efficiency of the Serbian financial market and the success of banks in the years to come.

The aim of the research is to analyse the level of implementation of international corporate governance principles in the national banking sector and to assess the adequacy and strength of the legal and regulatory framework of the Republic of Serbia to enable and support such an act. The subject of the research are the basic principles and legislation of corporate governance in banks. The importance of the research is reflected in the assessment of the capacity of the legislation of the Republic of Serbia to remain relevant in modern, changeable market conditions and create an adequate framework for the

\footnotetext{
${ }^{1}$ Polo, A., Corporate Governance of Banks: The Current State of the Debate. (2020, June 20). Available at: http://dx.doi.org/10.2139/ssrn.958796

${ }^{2}$ Kern, A., Corporate Governance and Banking Regulation: CFAP Working Paper 17. (2020, June 23). Available at: http://www.dspace.cam.ac.uk/handle/1810/225166

${ }^{3}$ Denčić-Mihajlov, K. (2009). Reforms of Corporate Governance and Takeover Regulation: Evidence from Serbia. South-Eastern Europe Journal of Economics, 7 (2), p. 206.
} 
implementation of the corporate governance principles in the Serbian banking sector. The methodology used for achieving the research objectives includes a descriptive method, analysis and synthesis technique, as well as analysis of the content of laws, reports, and available literature of reference domestic and foreign authors.

\section{Literature review on corporate governance}

The ICSI Institute defines corporate governance as a blend of rules, regulations, laws, and voluntary practices that enable corporations to attract financial and human capital, perform efficiently, and thereby maximise long term value for the shareholders besides respecting the aspirations of multiple stakeholders, including the society. ${ }^{4}$ Zattoni emphasizes that, in a narrower sense, corporate governance represents the composition of the multiple processes on the basis of which the board of directors nurtures responsibilities towards shareholders and engages in providing maximum income for them; while, in a broader sense, corporate governance represents a set of legal, cultural and institutional arrangements that improve the management of the corporation. ${ }^{5}$ The OECD states that corporate governance involves a set of relationships between a corporation's management, its board, shareholders and other stakeholders; and provides the structure through which the objectives of the corporation are set, and the means of attaining those objectives and monitoring performance are determined. ${ }^{6}$ The International Finance Corporation defines corporate governance as the structures and processes by which corporations are directed and controlled. ${ }^{7}$ The Chamber of Commerce and Industry of Serbia views corporate governance as a set of rules and behaviors that determine how capital companies are managed and controlled, strategically regulating relations between managers, members of the supervisory board, the board of directors, shareholders and other stakeholders. ${ }^{8}$

Vignjević-Đorđević states that the system of corporate governance refers to the synergy of laws, efficient institutions, professional chambers, and

\footnotetext{
${ }^{4}$ Gopalsamy, N. (2006). A Guide to Corporate Governance, New Delhi, New Age International, p. 21.

${ }^{5}$ Kukobat, L., Tešanović, S., Kukić, S., Korporativno upravljanje u Srbiji - problemi malih akcionara [Corporate Governance in Serbia - Problems of Small Shareholders]. (2020, Jun 28). Available at: http://portal.finiz.singidunum.ac.rs/Media/files/2016/111-116.pdf

${ }^{6}$ OECD. (2015). G20/OECD Principles of Corporate Governance, Paris, OECD Publishing, p. 9.

${ }^{7}$ International Finance Corporation. (2011). Korporativno upravljanje - priručnik [Corporate Governance - Handbook], Beograd, International Finance Corporation, p. 5.

${ }^{8}$ Kodeks korporativnog upravljanja [Corporate Governance Code], Službeni glasnik RS, br. 99/12.
} 
business ethics; and that quality corporate governance is based on responsibilities aimed at preserving the interests of shareholders and other stakeholders of a corporation. ${ }^{9}$ Borojević and co-authors point out that the corporate governance emphasizes and promotes fairness, responsibility, and transparency; stimulates the adoption of international accounting standards and good financial practices; ensures that management, board members, shareholders, and other stakeholders are aware of their role and responsibilities in the corporation; and ensures that the rights of all participants in the management chain are respected. ${ }^{10}$ Dukić-Mijatović emphasizes that the essence of quality corporate governance is reflected in finding the best model for the board of directors to set corporate goals, manage day-to-day operations, communicate with shareholders, and organise business with respect to the current regulations. ${ }^{11}$

\section{Principles of corporate governance in the banking sector of the Republic of Serbia}

The globalisation of banking markets has raised important issues regarding corporate governance regulation for banking institutions. ${ }^{12}$ The OECD Principles of Corporate Governance, as the only internationally recognized corpus of governance principles, have found their application in banking. They have gained worldwide recognition as an international benchmark for sound corporate governance, and in addition to banks, they are actively used by governments, regulators, and investors, both in OECD and in non-OECD countries. Key to the success of the Principles is in the fact that they are principles-based and non-prescriptive so that they retain their relevance in varying legal, economic, and social contexts. ${ }^{13}$ Thus, they provide non-binding standards and good customs, as well as application instructions adaptable to

\footnotetext{
${ }^{9}$ Vignjević-Đorđević, N. (2014). Corporate Governance - State and Trends in the Region: A Regulatory Approach. Ekonomika preduzeća, 62 (5-6), p. 264.

${ }^{10}$ Borojević, K., Nestorović, O., Borojević, N. (2017). Koncept korporativnog upravljanja i društvene odgovornosti u cilju unapređenja poslovanja preduzeća [Concept of Corporate Governance and Social Responsibility in order to Improve Business of Companies]. SVAROG naučno-stručni časopis za prirodne i društvene nauke, 15 (1), p. 109.

${ }^{11}$ Dukić-Mijatović, M. (2011). Korporativno upravljanje i kompanijsko pravo Republike Srbije [Corporate Governance and Companies Business Law of the Republic of Serbia]. Pravo - teorija i praksa, 28 (1-3), p. 20.

${ }^{12}$ Kern, A. op. cit.

${ }^{13}$ Jesover, F., Kirkpatrick, G. (2005). The Revised OECD Principles of Corporate Governance and their Relevance to Non-OECD Countries. Corporate Governance: An International Review, 13 (2), p. 130.
} 
the specific market conditions of many countries. The Principles are intended to provide strong but flexible references for policy makers and market participants. However, they are not a substitute for government, semi-government, or private sector initiatives for the development of the best corporate governance practices. ${ }^{14}$

The OECD Principles of Corporate Governance cover six key areas and the main features of the "ideal" corporate governance framework in banking are listed below: ${ }^{15}$

1. Ensuring the basis for an effective corporate governance framework - The corporate governance framework in banking needs to be developed taking into account its impact on market integrity, overall economic performance, the promotion of transparent and functional markets, and the incentives it creates for market participants. In addition, legal and regulatory requirements in the field of corporate governance in banking should be transparent, applicable and in line with the rule of law; the division of responsibilities between different jurisdictions should be clearly articulated and shaped to serve the public interest; and supervisory, regulatory and executive bodies should have the authority, integrity, and resources to perform their duties professionally;

2. The rights of shareholders, the equitable treatment of shareholders, and key ownership functions - The bank is a shareholder body composed of individuals and/or institutions whose interests, goals, investment horizons, and ambitions vary. Regardless of their diversity, the basic rights of all shareholders should be equal and include the right on secure methods of registration of ownership, transfer of shares, timely and regular receipt of relevant information about the bank, participation and voting at the general shareholders' meetings, participation in election and replacement of board members, as well as the right to participate in the bank's profit. Violation of the rights of minority shareholders, i.e. unequal treatment of shareholders of different classes, is one of the biggest weaknesses of corporate governance practices in banking. The protection of the rights

\footnotetext{
${ }^{14}$ OECD. (2004). OECD Principi korporativnog upravljanja [OECD Principles of Corporate Governance], Beograd, Misija OEBS-a u Srbiji i Crnoj Gori, p. 8., OECD. G20/OECD Principles of Corporate Governance, p. 11.

${ }^{15}$ Jesover, F., Kirkpatrick, G. op. cit. pp. 128-130., OECD. OECD Principi korporativnog upravljanja [OECD Principles of Corporate Governance], op. cit., p. 12-58., OECD. G20/OECD Principles of Corporate Governance, op. cit., pp. 13-54.
} 
of minority shareholders requires the effective application of special procedures concerning the development of fair valuation, strict openness requirements, and the approval of a qualified majority of board members at the general shareholders' meetings. The level of harmonization of key ownership roles often dictates the level of efficiency of corporate governance in banking in modern market conditions. Banking relations are often characterized by different and sometimes conflicting interests of the main bodies of the bank, i.e. boards of shareholders, boards of directors, and members of the supervisory board. Conflicts of interest most often arise between shareholders (majority against minority shareholders; shareholders who control the bank against those who do not control it; individual against institutional shareholders), but also conflicts of interest between board members (executive against non-executive members; external against internal members; independent against dependent members, etc.) are not rare. Each of the mentioned opposing interests must be timely noticed, carefully monitored, and resolved or maintained in balance;

3. Institutional investors, stock exchanges, and other intermediaries The corporate governance framework should provide sound incentives throughout the investment chain and ensure that stock exchanges function in a way that contributes to good corporate governance. This principle promotes the stance that institutional investors should disclose their overall corporate governance standards and voting policies relating to their investments, and that stock exchanges and other intermediaries should play a significant role in improving corporate governance - stock exchanges by establishing and implementing requirements that promote efficient corporate governance of listed issuers; and other intermediaries by performing the role of supervisors of bank's operations;

4. The role of stakeholders in corporate governance - The corporate governance framework should recognise the rights of stakeholders established by law or through mutual agreements and encourage active cooperation between banks and stakeholders in creating wealth, jobs, sustainability, and financial stability. Stakeholders involved in the corporate governance process should have timely and regular access to relevant, necessary and reliable information; the right to freely communicate to the bank's boards their opinion on unethical and/or illegal practices, and the right to become part of the 
supervisory system in order to limit the excessive influence of the management on the bank;

5. Disclosure and transparency - The corporate governance framework should ensure that timely and accurate disclosure is made on all material matters regarding the bank, including the financial situation, performance, ownership, and governance. Specifically, disclosures should include information on bank's financial and business results, bank objectives, related party transactions, foreseeable risk factors, board members (including their qualifications, selection process, board membership in other banks/corporations, etc.), compensation policies for board members and key executives; but also information on significant ownership of shares, voting rights, governance structures and policies. All mentioned information should be prepared and published with respect to accounting and high quality financial and non-financial disclosure standards;

6. The responsibilities of the board - The corporate governance framework should ensure the strategic guidance of the bank, the effective monitoring of management by the board, and the board's accountability to the bank and the shareholders. In other words, board members should act on the basis of complete information, in good intention, with due care, and in the best interest of the bank and shareholders. The board should strive to apply high moral standards, monitor and resolve conflicts of interest, as well as to establish relevant procedures regarding transactions, integrity, and efficiency of accounting and financial reporting.

Inspecting the national legislation, it was noticed that corporate governance in the banking sector of the Republic of Serbia is completely based on the OECD Principles of Corporate Governance, but also characterised by certain specific characteristics: ${ }^{16}$

1. Concentrated ownership - In the 1990s, relatively dispersed ownership structures emerged in the Republic of Serbia, primarily and almost exclusively in corporations/banks that, in accordance with the Law on Property Transformation from 1997 privatised social capital through free distribution of shares (in the first round), and by selling shares under special conditions (in the second round). After the division, i.e. sale under special conditions,

\footnotetext{
${ }^{16}$ International Finance Corporation. op. cit. pp. 21-22.
} 
the secondary stock trading in most cases resulted in the concentration of ownership in the hands of a smaller number of shareholders. Almost parallel to this trend, since 2001, the privatisation model adopted by the Law on Privatisation has promoted the majority participation of only one or a small number of shareholders in the corporation's/bank's capital. Thanks to the aforementioned events numerous corporations/banks in the Republic of Serbia today are controlled by a small group of shareholders or one shareholder with a controlling package of shares. The negative effects of this concentrated ownership structure are reflected in the fact that it often leads to abuse of minority shareholders' rights, which together with insider domination and weak protection of external shareholders/investors greatly affects the quality of corporate governance and financial market development in the Republic of Serbia;

2. Relationship between ownership and control - Most shareholders of Serbian banks are at the same time general directors and members of their boards, which gives them the role of supervisors of the bank's operations. In such financial institutions, the separation of ownership and control is often noticeable only on paper, and the consequences are mainly weak accountability and control structures, abuses through related party transactions, and poor and inadequate disclosure practices;

3. Inexperienced and inadequate corporate bodies - Lack of experience in the field of corporate governance is a major obstacle to the development of the Serbian financial market. Strong, conscientious, and independent bodies of the bank are still a rarity in national banking, and the members of the mentioned bodies often do not have the appropriate knowledge and skills to perform corporate governance tasks. In such circumstances, the biggest challenges are the establishment of a quality system of internal supervision at all levels of the bank's operations and the perception of its importance for "early diagnosis" and elimination of potential business threats. 


\section{Legal and regulatory framework of corporate governance in the banking sector of the Republic of Serbia}

As the implementation of international corporate governance standards in banking systems due to differences in legal and institutional structures and business practices between markets may result in systemic risks for different jurisdictions, this application procedure should be supported by regulations that specify rules and procedures for corporate governance in the specific political, economic and legal system of a state. ${ }^{17}$ The balance between laws, regulations, and principles of corporate governance varies from country to country, and depends on national history, legal tradition, judicial efficiency, and political structure, on the one hand, and the stage of development of the bank in which the principles are adopted, on the other. ${ }^{18}$

Blair points out that corporate governance standards in banking include legal framework, i.e. contract, compensation, property, bankruptcy, and internal information and control laws; laws governing operations of financial institutions and securities operations; decision-making practices on boards of directors and supervisory boards; and various aspects of corporate finance. By adopting corporate governance practices, the bank accepts business and financial responsibility in terms of efficient management of the entrusted resources of the founders, owners, creditors, employees, and the state. ${ }^{19}$

The benefits that banks, thanks to an adequate legal and regulatory framework of corporate governance, achieve directly through the process of implementing corporate governance standards and principles are better performance, easier access to capital markets, more favorable conditions for raising new capital, and better reputation. ${ }^{20}$ However, regulating the sphere of corporate governance in banking brings several challenges in addition to the benefits. Examples are situations where regulation imposes restrictions on ownership, promotes deposit insurance, reduces permitted business, or applies coefficients that negatively affect the competition in the industry. ${ }^{21}$

\footnotetext{
${ }^{17}$ Kern, A. op. cit.

${ }^{18}$ OECD. (2004). Corporate Governance: A Survey of OECD Countries, Paris, OECD Publishing, p. 40.

${ }^{19}$ Kukobat, L., Tešanović, S., Kukić, S. op. cit.

${ }^{20}$ Kodeks korporativnog upravljanja [Corporate Governance Code]. op. cit.

${ }^{21}$ De Andres, P., Vallelado, E. (2008). Corporate Governance in Banking: The Role of the Board of Directors. Journal of Banking \& Finance, 32 (1), p. 2570.
} 
Laws and regulations in most Southeast European countries are close to international standards on major corporate governance issues. ${ }^{22}$ The legal and regulatory framework of corporate governance in Serbian banking is largely determined by the Law on Banks ${ }^{23}$ whose application has been mandatory since 2006, but also by the Law on Business Companies, ${ }^{24}$ Insurance Law, ${ }^{25}$, Law on Capital Market, ${ }^{26}$ and Law on Voluntary Pension Funds and Pension Schemes. ${ }^{27}$ Today, the Law on Banks of the Republic of Serbia contains a comprehensive and effective framework of corporate governance in banking. Its adoption is the result of the harmonization of Serbian financial legislation with European Union regulations and Basel II standards, as well as harmonization of regulations in the banking sector with standards and principles governing some other areas of financial operations in the Republic of Serbia. ${ }^{28}$ In addition to the mentioned laws, i.e. the general legal and regulatory framework, there are also regulations whose "interest" is exclusively oriented towards the issue of corporate governance in capital companies. Corporate governance codes are the most prominent among them and are defined as statements of corporate governance practices of the corporation/bank that are based on the principles and standards of corporate governance. ${ }^{29}$ The main goals of the codes are to bring the management system of the corporation/ bank closer to employees, external associates, and the public in a concise and understandable way, but also to positively influence the regulation of relations between management, supervisory board, shareholders and employees. ${ }^{30}$ The most important regulations in the Republic of Serbia are the Corporate Governance Code of the Chamber of Commerce and Industry of Serbia, the Corporate Governance Code of the Belgrade Stock Exchange, and the Rules and Procedures of the Belgrade Stock Exchange. Pistor and co-authors point

\footnotetext{
${ }^{22}$ OECD. (2003). Stability Pact - South East Europe Compact for Reform, Investment, Integrity, and Growth: White Paper on Corporate Governance in South East Europe, Paris, OECD Publishing, p. 7.

${ }^{23}$ Zakon o bankama [Law on Banks], Sl. glasnik RS, br. 107/05, 91/10 i 14/15.

${ }^{24}$ Zakon o privrednim društvima [Law on Business Companies], Službeni glasnik RS, br. 36/11, 99/11, 83/14 - dr. zakon, 5/15, 44/18, 95/18 i 91/19.

${ }^{25}$ Zakon o osiguranju [Insurance Law], Službeni glasnik RS, br. 139/14.

${ }^{26}$ Zakon o tržištu kapitala [Law on Capital Market], Službeni glasnik RS, br. 31/11, 112/15, 108/16 i $9 / 20$.

${ }^{27}$ Zakon o dobrovoljnim penzijskim fondovima i penzijskim planovima [Law on Voluntary Pension Funds and Pension Schemes], Službeni glasnik RS, br. 85/05 i 31/11.

${ }^{28}$ Obradović, Z. (2019). Ocena kvaliteta korporativnog upravljanja u bankama u Srbiji [Assessment of Bank Corporate Governance in Serbia]. Revizor, 22 (86), p. 76.

${ }^{29}$ International Finance Corporation. op. cit. p. 59.

${ }^{30}$ Kukobat, L., Tešanović, S., Kukić, S. op. cit.
} 
out that the Republic of Serbia has come a long and strenuous way in including the principles of corporate governance in the national legislative framework; and that, in summary, integration can be evidenced by the fact that the OECD Principles of Corporate Governance, in a slightly modified form, are permeated through the structure of a numerous Serbian regulations and legal acts. $^{31}$

\section{Conclusion}

Corporate governance mechanisms in the financial sector of the Republic of Serbia are more complex than those that characterize corporate governance in the non-financial sector. The negative effects that arise as a result of failures in banking management processes can relatively easily spill over into the entire market and cause systemic risk and delays in the functioning of the market economy. Consequently, the caution with which defining corporate governance standards in banking is conducted must be exceptional, and corporate governance activities must be supported by a strong and stable legal and regulatory framework. Thus, in order to adequately apply the principles of corporate governance in banking, the state must actively work on strengthening and updating the existing legal and regulatory framework of corporate governance.

Conducting an assessment of the capacity of existing legislation to remain relevant in modern, changing market conditions and create an adequate framework for implementation of the principles of corporate governance in the Serbian banking sector resulted with the conclusion that the legal and regulatory framework of the Republic of Serbia in the field of corporate governance is comprehensive, adequate and up-to-date. More precisely, numerous laws (Law on Banks, Law on Business Companies, Law on Capital Market, etc.), as well as regulations (Corporate Governance Code of the Chamber of Commerce and Industry of Serbia, Corporate Governance Code of the Belgrade Stock Exchange, etc.) adequately define provisions and standards in corporate governance which greatly facilitate the implementation of corporate governance principles by banks. Nevertheless, regardless of the general assessment of the aforementioned legal and regulatory framework as up-todate and appropriate, there is a space for further improvements, especially in the sphere of improving standards related to the protection of minority

\footnotetext{
${ }^{31}$ Manić, S., The Questionable Achievements of Corporate Governance: Case of Serbia. (2020, June 25). Available: https://www.researchgate.net/publication/237627526
} 
shareholders' rights, promoting the application of corporate governance principles in practice, approximation to international financial reporting standards, encouraging stakeholders to participate in supervisory processes, strengthening the judicial system, creating efficient and exemplary boards, etc.

The conclusion is that the national banking sector is strengthened and supported by legislation that recognizes and adequately evaluates the principles of corporate governance, which facilitates the application of internationally recognised standards in national banking in the field of corporate governance, and results in better performance, easier access to capital markets, more favorable conditions for raising new capital, and a better corporate reputation of banks.

\section{Jolović Nevena}

Doktorand, Ekonomski fakultet u Subotici, Univerzitet u Novom Sadu

\section{Dukić Mijatović Marijana}

Dr, Docent, Ekonomski fakultet u Subotici, Univerzitet u Novom Sadu,

Dr, Redovan profesor, Pravni fakultet za privredu i pravosuđe u Novom Sadu, Univerzitet Privredna akademija u Novom Sadu

\section{PRINCIPI KORPORATIVNOG UPRAVLJANJA U BANKAMA I LEGISLATIVE REPUBLIKE SRBIJE}

REZIME: Kompleksni odnosi, neretka odvojenost funkcija vlasništva, upravljanja i kontrole u bankama, kao i turbulentni i promenjivi tržišni uslovi čine da su pravični i transparentni mehanizmi korporativnog upravljanja od izuzetne važnosti za ove finansijske institucije. "Kultura" korporativnog upravljanja inkorporirana je u bankarski sektor Republike Srbije, a temelji se na nacionalnim legislativama i međunarodnim standardima upravljanja. Cilj istraživanja je analiza stepena implementacije međunarodnih principa korporativnog upravljanja u srpskom bankarskom sektoru i ocena adekvatnosti i snage nacionalnog pravnog i regulatornog okvira da omogući i podrži takav čin. Za potrebe izrade rada korišćene su: deskriptivna metoda, tehnika analize i sinteze, kao i analiza sadržaja zakona, izveštaja, i dostupne nacionalne $\mathrm{i}$ inostrane literature $\mathrm{u}$ oblasti kor- 
porativnog upravljanja. Rezultat istraživanja je potvrđen stav da pravni i regulatorni okvir korporativnog upravljanja u bankarskom sektoru Republike Srbije implementaciju međunarodnih principa korporativnog upravljanja čini mogućom i u dovoljnoj meri je podržava.

Ključne reči: korporativno upravljanje, bankarstvo, Zakon o bankama, Republika Srbija.

\section{References}

1. Borojević, K., Nestorović, O., Borojević, N. (2017). Koncept korporativnog upravljanja i društvene odgovornosti u cilju unapređenja poslovanja preduzeća [Concept of Corporate Governance and Social Responsibility in order to Improve Business of Companies]. SVAROG - naučno-stručni časopis za prirodne i društvene nauke, 15 (1), pp. 108-119

2. De Andres, P., Vallelado, E. (2008). Corporate Governance in Banking The Role of the Board of Directors. Journal of Banking \& Finance, 32 (1), pp. 2570-2580

3. Denčić-Mihajlov, K. (2009). Reforms of Corporate Governance and Takeover Regulation: Evidence from Serbia. South-Eastern Europe Journal of Economics, 7 (2), pp. 205-227

4. Dukić-Mijatović, M. (2011). Korporativno upravljanje i kompanijsko pravo Republike Srbije [Corporate Governance and Companies Business Law of the Republic of Serbia]. Pravo - teorija i praksa, 28 (1-3), pp. 15-22

5. Gopalsamy, N. (2006). A Guide to Corporate Governance, New Delhi, New Age International

6. International Finance Corporation. (2011). Korporativno upravljanje priručnik [Corporate Governance - Handbook], Beograd, International Finance Corporation

7. Jesover, F., Kirkpatrick, G. (2005). The Revised OECD Principles of Corporate Governance and their Relevance to Non-OECD Countries. Corporate Governance: An International Review, 13 (2), pp. 127-136

8. Kern, A., Corporate Governance and Banking Regulation: CFAP Working Paper 17. Available: http://www.dspace.cam.ac.uk/handle/1810/225166

9. Kodeks korporativnog upravljanja [Corporate Governance Code], Službeni glasnik RS, br. 99/12

10. Kukobat, L., Tešanović, S., Kukić, S., - Korporativno upravljanje u Srbiji - problemi malih akcionara [Corporate Governance in Serbia - Problems 
of Small Shareholders]. Available: http://portal.finiz.singidunum.ac.rs/ Media/files/2016/111-116.pdf

11. Manić, S., The Questionable Achievements of Corporate Governance: Case of Serbia. Available: https://www.researchgate.net/publication/ 237627526

12. Obradović, Z. (2019). Ocena kvaliteta korporativnog upravljanja u bankama u Srbiji [Assessment of Bank Corporate Governance in Serbia]. Revizor, 22 (86), pp. 67-82

13. OECD. (2003). Stability Pact - South East Europe Compact for Reform, Investment, Integrity, and Growth: White Paper on Corporate Governance in South East Europe, Paris, OECD Publishing

14. OECD. (2004). Corporate Governance: A Survey of OECD Countries, Paris, OECD Publishing

15. OECD. (2004). OECD Principi korporativnog upravljanja [OECD Principles of Corporate Governance], Beograd, Misija OEBS-a u Srbiji i Crnoj Gori

16. OECD. (2015). G20/OECD Principles of Corporate Governance, Paris, OECD Publishing

17. Polo, A., Corporate Governance of Banks: The Current State of the Debate. Available: http://dx.doi.org/10.2139/ssrn.958796

18. Vignjević-Đorđević, N., (2014). Corporate Governance - State and Trends in the Region: A Regulatory Approach. Ekonomika preduzeća, 62 (5-6), pp. 264-280

19. Zakon o bankama [Law on Banks], Službeni glasnik RS, br. 107/05, 91/10 i $14 / 15$

20. Zakon o dobrovoljnim penzijskim fondovima i penzijskim planovima [Law on Voluntary Pension Funds and Pension Schemes], Službeni glasnik $R S$, br. 85/05 i 31/11

21. Zakon o osiguranju [Insurance Law], Službeni glasnik RS, br. 139/14

22. Zakon o privrednim društvima [Law on Business Companies], Službeni glasnik $R S$, br. 36/11, 99/11, 83/14 - dr. zakon, 5/15, 44/18, 95/18 i 91/19

23. Zakon o tržištu kapitala [Law on Capital Market], Sl. glasnik $R S$, br. $31 / 11,112 / 15,108 / 16$ i $9 / 20$

\section{Acknowledgements}

The preparation of this paper is financed by the Ministry of Education, Science and Technological Development of the Republic of Serbia. 